\title{
Tax Compliance of Village-Owned Enterprises Based on Government Regulation (PP) No 23 Year of 2018
}

\author{
Pasca Dwi Putra $^{1 *}$, Charles Fransiscus Ambarita ${ }^{2}$, Baginda Halim Simatupang ${ }^{3}$ \\ Department of Business Education, Universitas Negeri Medan, Indonesia ${ }^{1,2,3}$ \\ *sgacenter@gmail.com
}

\begin{abstract}
Taxes are source of income for a country to finance its activities in providing facilities and infrastructure as well as services to the community, while one of the largest sources of tax revenue comes from Micro, Small and Medium Enterprises, which in this study focus on Village-Owned Enterprises (BumDes) Focus This research is with the implementation of Government Regulation No. 23 of 2018 which is an improvement from Government Regulation No. 46 of 2016 concerning tax rates for SMEs which were previously at $1 \%$ to $0.5 \%$. The purpose of this study is to provide fundamental knowledge about the factors that influence an SME to comply with paying taxes. Operationally, this research has the following objectives: (a) explore factors that influence MSMEs to comply with paying taxes, (b) test tax planning practices for MSMEs, (c) understandings for the government to find out what factors influence MSMEs to comply with paying taxes, (d) knowing the dominant factor for MSMEs as a driver of tax compliance. This research was tested using multiple linear regressions to determine the dominant factor. The results of this study indicate that only understanding, awareness, and sales variables affects the tax compliance, while socialization and trust have insignificant effect.
\end{abstract}

Keywords: Tax Compliance, Understanding of Tax, Awareness, Sales, Public Trust.

\section{Introduction}

Economic growth and business competition between countries is very fast and tight now that requires the government to find ways to be able to compete. One of them is through the provision of facilities and infrastructure to support the development and equitable distribution of welfare and the provision of services to the wider community. Development is not only done in urban areas but also in rural areas. The goal is that rural communities can benefit from the development. In achieving this increase in economic growth, the government provides stimulation to the community to be more independent and not rely on limited employment. One of the stimuli carried out by the government is through the independence of the community by creating micro, small and medium enterprises (MSMEs). In some countries, especially developing countries, MSMEs play an important role in development, especially in making a large contribution to the country's GDP $[1,2,3]$. Besides that, in creating a large and successful company begins with a small company so that it is expected that with the development of micro, small, and medium-sized companies in the future can increase the number of large companies [4]. The government aims to increase MSME growth because it has an important role in reducing poverty, unemployment, a large contribution to a country's GDP through tax payments, investment mobilization, and the use of raw materials in a region 
[4,5]. It is expected that with the increase in the number of MSMEs the community will be more independent, which in turn will contribute greatly to state revenues.

Besides that, in developing an area or country, adequate and sustainable funding is needed. One significant source of funding in development is through taxes collected from the community [6,7]. Tax is very important in the development of a country especially developing countries whose purpose is to finance state activities and reduce state dependence on assistance from international and state financial institutions $[4,8,9]$. This tax is obtained from the activities of both small companies such as MSMEs and large companies. The tax collected does not only come from the central government but also from the village, district, and provincial levels, which will later be returned to the regions for the purpose of welfare and community development. The main focus of the current government is to collect taxes from MSMEs. This number of MSMEs has increased every year so that it is projected that the amount of tax received will also increase [10]. Therefore, it is necessary to have a special policy for taxation of MSMEs so that businesses can help develop a country's awareness of paying taxes.

The number of MSMEs has increased every year. According to data from the Ministry of Cooperatives and MSMEs the number of MSMEs in 2016 was 61 million and increased to 63 million in 2017 or an increase of $2.06 \%$ while large businesses $1.67 \%$ so it can be seen that the largest increase in MSMEs [11]. In addition, the contribution to GDP received from 2016 to 2017 increased by $9.92 \%$ so that MSMEs played an important role as a source of funding for a country. However, the increase in the number of MSMEs currently available is not proportional to the increase in the amount of GDP received by the government. Previously, the government issued Government Regulation No. 46 of 2016 which imposed a 1\% tax on MSMEs with a turnover of up to 4.8 billion rupiahs / year. The government objectives are increasing revenue from the MSME sector and also stimulating MSMEs to be able to arrange their books to be more orderly through providing transaction evidence [7]. Through the implementation of PP No. 46, the government obtained a tax of $57.48 \%$ so that the potential is greater compared to other sources of income. But in 2017, revenue from MSMEs decreased and did not reach the target set. According to tax data, it shows that in 2017 only reached the target of $60 \%$ of the target set ie only received 3-4 trillion. This is a concern for the government with regard to reducing the amount of revenue coming from MSMEs while the amount is increasing every year.

Several studies have shown that there is a reluctance of MSMEs in developing countries to pay taxes $[4,5,12,13]$. This is due to many factors such as lack of accountability and transparency in the use of taxes for the development of the country so that there is a lot of corruption, large tax costs, the complexity of the tax system adopted in an state, double taxation granted, large tax rates, lack of knowledge of tax laws, amount of revenue obtained, justice, motivation, audit levels, law enforcement, lack of accounting knowledge, and other factors $[1,6,7,14,15,16]$. The impact of the lack of compliance of business practitioners in making taxes is that many MSMEs report a small portion of their taxable income so that the amount of tax received is small. Awareness of business people in paying taxes related to compliance paying taxes, as well as the separation of the amount of revenue obtained [18]. The need of tax policy is to make taxpayers to voluntarily and consciously pay taxes for economic growth and resource use.

A factor that often arises in tax compliance is the cost of tax compliance. Tax compliance costs are the overall costs incurred by taxpayers and third parties in the process of ensuring that they meet the provisions of the tax law to tax authorities [1]. With the existence of these compliance costs it becomes a burden for MSMEs to pay more tax amounts beyond the 
obligations that must be paid. In addition, the negative impact of compliance costs is the slow growth of MSMEs because they must focus on how MSMEs can meet tax payments in accordance with applicable laws and regulations. In addition, most of the SMEs have insufficient knowledge related to tax regulations, thereby increasing the costs of compliance with MSMEs. Therefore, important attention needs to be paid to the government to increase the amount of revenue that comes from MSME taxes through growing awareness of businesses in paying taxes.

The problem of this research focuses on finding the problems faced by research subjects in growing awareness of paying taxes. Besides that, this research is related to the development of teaching materials and empirical evidence of tax planning and financial reporting materials in introductory accounting courses. This research is a continuation of previous research relating to tax avoidance conducted by companies with research subjects listed in the stock market in several countries such as Indonesia, Malaysia, and Singapore. The results of the study show that in each country the practice of tax avoidance is different by looking at the opportunities of the tax regulations that apply to a country. The companies are large companies which have a large turnover as well. But this research was conducted on small companies because it has a large contribution to the country's GDP compared to large companies. The purpose of this study is to find empirical evidence of tax planning practices by the public through tax compliance. In addition, this research also deals with how business people prepare their financial statements and financial planning in reporting their taxable income to the government. The results of this study can contribute both to researchers, the community, and the government related to tax payment compliance by the community, especially MSMEs. The results of this study also provide empirical evidence to students to see the practice of taxation in the community so that students know the practice of taxation in the community.

One area that has a large number of MSMEs comes from the countryside. If observed, many rural communities use their local wealth to create businesses to improve their welfare. But in building a micro, small, and medium-sized business requires substantial funding. Law No. 6 of 2014 relating to villages, a Village-Owned Business Entity (BumDes) was formed, the purpose of which was to provide a forum for village communities to utilize the resources of their villages through a family spirit and mutual cooperation. As for the results of this BumDes used for business development and village development, BumDes is part of the business of MSMEs so that its existence helps in improving the welfare of the community. Through this BumDes, it is hoped that the income that the village receives will also help contribute to taxes for the country. Reflections on UMKM tax revenue in 2017 which experienced a decline and only reached the target of $60 \%$, which is 3-4 trillion, it is necessary to look at the determinants of the level of tax compliance from village-owned enterprises that are part of MSMEs through PP No. 23 of 2018 whose rates are experiencing the previous decrease was $1 \%$ to $0.5 \%$ with the company's turnover reaching $4.8 \mathrm{M} /$ year.

Tax is a source of income for a country, especially developing countries. This tax will be used to finance a country's activities. Indonesia is one of the countries that give special attention to the acquisition of taxes used to finance the activities of the country. Therefore, it is important in preparing regulations in determining the appropriate tax rates so that the tax received can be maximally.

Tax payments are relating to compliance and awareness of taxpayers to pay taxes. Tax according to the KUP Law No. 28/2007 was a levy imposed by the government on the community in order to realize the shared ideals of community prosperity. So the purpose of collecting taxes is to provide facilities and infrastructure as well as services to the community 
where the benefits are not directly obtained [19]. The tax function is divided into 2 y regular end functions, budget functions. Where the regular end function as a regulator to achieve goals in the field of financial finances based on the function of the budget where the tax serves as financing development and spending for the welfare of the people.

In relation to taxpayers, awareness and motivation are needed. Awareness and motivation to pay taxes related to one theory, namely the theory of planned behavior or also called the theory of reasoned action [20]. This theory explains about how human behavior based on will with consideration to do or not do a behavior. This is based on the view of a person of what is seen so decides to act. In this case the awareness of taxpayers in paying taxes is based on the views of taxpayers on the benefits obtained so that they can assess what behavior must be done to carry out their tax obligations. Other theories related to tax awareness are fiscal and social psychology models. This theory explains the belief in a person to respond to social norms related to compliance with paying taxes to understand and predict human behavior. Based on the theory underlying tax compliance can be clearer that compliance in paying taxes is related to the awareness of a person to comply with applicable regulations in the community. In the awareness of paying taxes, one of the factors that reduce this awareness is the cost of compliance. Tax compliance costs are related to all costs incurred by companies outside of the tax obligations paid to ensure that the company is in accordance with applicable regulations [1]. Tax compliance is related to the awareness of taxpayers to pay and comply with applicable tax regulations [21]. Tax compliance is also related to ignorance in situations where taxpayers will reduce the amount of tax paid through income that is not reported in the short term [18]. From the individual side, the cost of tax compliance includes how someone to obtain enough knowledge to meet the legal requirements compile evidence in making tax calculations, tax returns, and other costs related to tax compliance. In relation to tax compliance, the type of tax paid is income tax, that is, the tax treatment that is imposed on taxpayers of all income received in a country within 1 tax period [19].

The object of this research is micro, small and medium enterprises which include Village-Owned Enterprises that are developed by villages in utilizing the resources owned by the village both natural and human. Micro, Small, and Medium Enterprises according to RI Law No. 20 of 2018 is divided into three namely:

1) Micro business is productive business owned by individuals and / or individual business entities.

2) Small Business is a productive economic business that stands alone, which is carried out by individuals or business entities that are not subsidiaries or non-branch companies that are owned, controlled, or become a part either directly or indirectly from Medium Enterprises or Large Enterprises.

3) Medium Business is a productive economic business that stands alone, which is carried out by individuals or business entities that are not subsidiaries or branch companies that are owned, controlled, become a part either directly or indirectly with a Small Business or Large Business with a net worth or annual sales results.

From the three definitions above, it shows that MSME is a productive economic enterprise that is established by both individuals and groups. One of the government development programs of UMKM in the countryside is a Village-Owned Enterprise (BumDes). This business entity was established based on RI Law No. 6 of 2014 concerning Villages. Previously, the village was a legal community unit that had the authority to regulate and manage government affairs, the interests of the local community based on community initiatives, original rights, and / or traditional rights recognized and respected in the government system of the Unitary State of the Republic of Indonesia [22]. Since 2014, each 
village has been given village funds aimed at managing the village to become more independent. One of the large fund allocations is the establishment of Village-Owned Enterprises whose purpose is to build rural communities through the establishment of business entities managed by village communities through a family spirit and mutual cooperation. This BumDes is engaged in economy and / or public services where the results are used for business development and village development. Because this business entity is engaged in the economic sector, the income obtained by this institution must be deposited to the state in the form of tax. It also aims to assist the country in obtaining income in developing and improving the economy. Based on the results of the study showed that MSMEs have low tax payment compliance $[1,4,5,6]$. Therefore, it is necessary to know the factors that influence MSMEs in having compliance in paying their taxes to the government. The factors in this study are the understanding of taxpayers against the applicable tax regulations, taxpayer awareness, the number of sales obtained, and public trust.

The first factor is an understanding of tax regulations. The understanding of taxation is a condition where taxpayers fulfill all tax obligations and carry out their tax rights [23]. This understanding shows that taxpayers know all the rules relating to taxes paid based on the provisions of tax legislation. The more understanding of taxpayers related to tax regulations, the more obedient to pay taxes. The second factor affecting tax compliance is the awareness of paying taxes. This awareness includes how taxpayers know and understand the amount of tax to be paid in accordance with applicable tax regulations. The more aware of the importance of food taxes the more obedient taxpayers to pay the amount of tax obligations. The third factor is the number of sales obtained. The basis for tax is the amount of sales obtained. From this amount the tax paid is calculated. Therefore, it is important to deliver actual sales information relating to tax compliance paid. The fourth factor affecting tax compliance is public confidence in the use of taxes. If the public sees fraud and improper use, it will cause public distrust of the use of taxes, which in turn will affect the public's reluctance to pay some of the taxes paid.

\section{Research Method}

This research is a quantitative study in which research uses data derived from answers to questionnaires given to respondents in the form of primary data. The questions given in the form of closed and open questions so that there is an opportunity to obtain information more related to compliance in paying taxes.

The location of this research is villages that have Village Owned Enterprises in Deli Serdang Regency, Langkat Regency, and Serdang Bedagai Regency. The results of this study are a reference to the deepening of learning planning material at the Faculty of Economics, State University of Medan.

The population of this research is Village-Owned Enterprises in Deli Serdang Regency, Langkat Regency, and Serdang Bedagai Regency. Sampling uses a random sampling method, especially a business entity that has been established for at least 1 year so that the amount of sales obtained for 1 year and the amount of tax paid.

The analysis technique used in interpreting and analyzing data uses multiple linear regression models to find out the factors that influence the compliance of MSME taxpayers in paying the amount of tax to the state. Before testing the model, classical assumptions are tested first. 


\section{Results and Discussion}

This research is a causal field research in which the aim is as an empirical proof related to tax planning and tax payment compliance by SMEs, especially BumDes. The results of this study become empirical learning material on taxation subjects relating to income tax paid by BumDes to the government. The research was conducted at Micro and Small Medium Enterprises including Village Owned Enterprises (BumDes) in Deli Serdang Regency. The number of BumDes is 88 units, including services, trade and manufacturing businesses.

\section{Hypothesis testing}

Hypothesis testing uses linear regression to see the effect of understanding taxation, socialization, awareness, sales, and trust towards MSME compliance, especially BumDes in paying taxes. The results of hypothesis testing can be seen in the table below:

Table 1. Hypothesis Testing

\begin{tabular}{|c|c|c|c|c|c|c|}
\hline & \multirow[t]{2}{*}{ Model } & \multicolumn{2}{|c|}{$\begin{array}{c}\text { Unstandardized } \\
\text { Coefficients }\end{array}$} & \multirow{2}{*}{$\begin{array}{c}\text { Standardized } \\
\text { Coefficients } \\
\text { Beta } \\
\end{array}$} & \multirow[t]{2}{*}{$\mathrm{t}$} & \multirow[t]{2}{*}{ Sig. } \\
\hline & & $\mathrm{B}$ & Std. Error & & & \\
\hline \multirow{6}{*}{1} & (Constant) & .984 & 3.672 & & .268 & .789 \\
\hline & Understanding of Taxation & .591 & .159 & .445 & 3.714 & .000 \\
\hline & Socialization & .111 & .116 & .075 & .958 & .341 \\
\hline & Awareness & .321 & .140 & .209 & 2.296 & .024 \\
\hline & Sales & 1.123 & .212 & .395 & 5.291 & .000 \\
\hline & Trust & -.334 & .253 & -.135 & -1.320 & .190 \\
\hline
\end{tabular}

a. Dependent Variable: tax compliance

$$
\mathrm{Y}=0,984+0,591+0,111+0,321+1,123-0,334
$$

Based on the table above it can be explained that:

a) Based on table 1 above shows that the variable understanding of taxation has a significant level of 0,000 so that it shows a significant effect on tax compliance.

b) The second variable, namely socialization, shows a significant level of 0.341 , thus indicating that socialization has no significant effect on tax compliance.

c) The third variable, namely awareness of paying taxes, shows a significant level of 0.024 , indicating a significant effect on tax compliance.

d) The fourth variable is sales, which shows a significant level of 0,000 so that it is concluded that there is a significant effect on tax compliance.

e) The fifth variable is trust which shows a significant level of 0.190 which shows no significant effect on tax compliance

\section{Discussion}

\section{Understanding of Taxation}

Understanding taxation is related to the knowledge of taxpayers, namely the executor of a Village-Owned Enterprise who understands the related amount of tax paid for activities from BumDes. This shows that the understanding of the importance of taxes and the tax calculation process makes BumDes obedient to pay taxes from their activities. The results of this study are in line with research conducted before which shows that knowledge has a positive effect 
on taxpayers' compliance with paying taxes [24,25,26]. The results of this study also indicate the importance of knowledge owned by BumDes in planning tax payments so that in the end by understanding the taxes to be paid, it is expected that there is ongoing compliance in paying taxes.

\section{Socialization}

Socialization does not significantly influence tax compliance. Socialization in this case is the participation of the government in submitting tax regulations to BumDes so that there is taxpayer compliance in paying a number of taxes from the proceeds obtained. Hypothesis testing results show that the significant value obtained is 0.341 so it can be concluded that there is no significant effect of socialization on tax compliance. The importance of the socialization of taxpayers is the government's effort in making people aware, especially entrepreneurs, in paying taxes. But this research shows no effect. No socialization has shown that whether or not socialization does not affect BumDes in raising awareness of paying taxes. Besides that, the government still lacks of socialization conducted so that the lack of compliance in paying taxes, but the results of this study contradict which shows that the importance of socialization of regulations related to taxation so that taxpayers comply with paying taxes [19].

\section{Tax Pay Awareness}

Awareness of paying taxes significantly affects tax compliance. Awareness of paying taxes is an attitude that arises from within the taxpayer, especially the owner of BumDes, to pay a number of taxes on the business income he gets to help development. Hypothesis testing results shows that the awareness of paying tax has a significant effect on the compliance of taxpayers paying a number of taxes based on PP No. 23 of 2018. This attitude arises because of the awareness of the importance of taxes paid as well as the obligations of taxpayers to the state so that they obediently pay taxes according to regulations applicable. The results of this study are in line with research conducted before which shows that awareness in paying taxes has a significant effect on tax compliance [26,27].

\section{Sales}

Sales have a significant effect on tax compliance. It shows that the gross income obtained by the taxpayer for the business carried out. These results indicate that taxpayers have an awareness that the income obtained must be deposited to the country whose purpose is to assist development. The results of this study are in line with research conducted before which shows that sales have a significant effect on tax compliance [28,29,30]. The greater the income earned shows the greater compliance in paying taxes so the importance of increasing company sales in showing compliance paying taxes.

\section{Taxpayer Trust}

Trust shows a person's belief in something that benefits him. The taxpayer's trust here is the belief that the taxpayer has for the tax benefits paid so that if the benefits obtained are higher than it shows more obedience in paying taxes. Hypothesis testing shows that trust does not have a significant effect on taxpayer compliance, especially BumDes in paying taxes. The results of this study contradict the research conducted before which shows that there is a significant effect of trust on tax compliance [31]. These results indicate the benefits received by the public so that taxpayers trust and obey in paying taxes. 


\section{Conclusions}

Based on the results of research that has been done, it can be concluded that understanding, awareness, and sales have an effect on tax compliance while the socialization and trust variables have no significant effect. The importance of government supervision in showing increased compliance in paying taxes from BumDes entrepreneurs. Besides that, socialization and benefits received are also important in increasing compliance in paying taxes so that it becomes an important concern for the government to improve taxpayer compliance, especially BumDes in paying taxes.

\section{References}

[1] Eragbhe, E., \& Modugu, K. P. Tax Compliance Costs of Small and Medium Scale Enterprises in Nigeria. International Journal of Accounting and Taxation, 2(1), 63-87 (2014).

[2] Inasius, F. Tax Compliance of Small and Medium. Accounting and Taxation, 7(1), 67-73 (2015).

[3] Vlachos, V. A., \& Bitzenis, A. Tax compliance of small enterprises in Greece. International Journal of Entrepreneurship and Small Business, 28(2/3), 380-389 (2016).

[4] Atawodi, O. W., \& Ojeka, S. A. Factors That Affect Tax Compliance among Small and Medium Enterprises (smes) in North Central Nigeria. International Journal of Business and Management, 7(12), 87-96 (2012).

[5] Akinboade, O. A. Correlates oftax Compliance ofsmall andmedium Size Businesses in Cameroon. Managing Global Transitions, 13(4), 389-413 (2017).

[6] Nduruchi, M. G., Makokha, E. N., \& Namusonge, G. S. Determinants of Tax Compliance among Small and Medium Enterprises in Bungoman County, Kenya. European Journal of Business and managementonline), 9(18), 46-51 (2017).

[7] Zawitri, S., \& Yuliana, E. S. Tingkat Kepatuhan Wajib Pajak Badan Usaha Mikro Kecil dan Menengah Setelah Diberlakukan Tarif 1 \% (Final) pph (Studi Kasus di KPP Pratama Pontianak). Jurnal Ekonomi Bisnis Dan Kewirausahaan, 5(2), 144-162 (2016).

[8] Weichenrieder, A. J. Centre Pour L'entrepreuriat, Les Pme et le Developpement Local Centre For Entrepreneurship, SMES \& Local Development Centre de Politique et d'Adminstration Fiscales Centre For Tax Policy and Administration Survey on the Taxation of Small and Medium-sized, 1-95 (2007).

[9] Marandu, E. E., Mbekomize, C. J., \& Ifezue, A. N. Determinants of Tax Compliance: A Review of Factors and Conceptualizations. International Journal of Economics and Finance, 7(9), 207-218 (2015).

[10] Maseko, N. Determinants of Tax Compliance in Small and Medium Enterprises in Zimbabwe. Journal of Economics and International Business Research (JEIBR), 2(3), 48-57 (2014).

[11] KEMENKOP UKM RI. Data Usaha Mikro, Kecil, Menengah (Umkm) Dan Usaha Besar (Ub) of 2012 - 2013 (2013). 
[12] Nyk, M. Tax Planning For Small and Medium Enterprises (SMES). Annuals of Marketing Management \& Economics, 2(1), 91-98 (2016).

[13] Wadesango, N., Mutema, A., Mhaka, C., \& Wadesango, V. Tax Compliance of Small and Medium Enterprises Through the Self-Assessment System : Issues and Challenges. Academy of Accounting and Financial Studies Journal, 22(3), 1-15 (2018).

[14] Smatrakalev, G. Tax Policy for small and Medium Enterprises. Oxford Journal: An International Journal of Business \& Economics, 2(1), 69-74 (2007).

[15] Ali, M., Fjeldstad, O.-H., \& Sjursen, I. H. Factors Affecting Tax Compliant Attitude in Africa: Evidence from Kenya, Tanzania, Uganda and South Africa. Centre for the Study of Africa, 1-26 (2013).

[16] Misu, N. B. A Review of Factors for Tax Compliance. Economics and Applied Informatics, 17(1), 69-76 (2011).

[17] Tatik. Potensi Kepatuhan Pembayaran Pajak Pada Pelaku UMKM (Usaha Mikro Kecil dan Menengah) Pasca Penerbitan Peraturan Pemerintah Nomor 23 Tahun 2018 ( =Studi Kasus Pada UMKM di Kabupaten Sleman-Yogyakarta). In Seminar Nasional dan Call for Paper Sustainable Competitive Advantage (SCA). (2018).

[18] Alm, J. What Motivates Tax Compliance?. Journal of Economic Surveys. 33(2), 1-36 (2019).

[19] Pamuji, A. R. Faktor-faktor yang Mempengaruhi Kepatuhan Pemilik Usaha Mikro, Kecil, dan Menengah (UMKM) dalam Memenuhi Kewajiban Perpajakan (Studi pada Wajib Pajak Pemilik UMKM Di KPP Pratama Malang Selatan). Jurnal Mahasiswa Perpajakan. 3(1), 1-9 (2014).

[20] Ajzen, I. Theory of planned behavior. Organizational Behavior and Human Decision Processes. 50, 179-211 (1991).

[21] James, S., \& Alley, C. Tax compliance, self-assessment and tax administration University of Exeter, University of Waikato. Journal of Finance and Management in Public Services. 2, 27-42 (2002).

[22] Presiden Republik Indonesia - Dewan Perwakilan Rakyat. Undang - Undang Republik Indonesia Nomor 6 Tahun 2014 Tentang Desa (2014).

[23] Nurmanto, S. Pengantar Perpajakan (2nd ed.). Jakarta: Granit (2003).

[24] Fahluzy, S. F., \& Agustina, L. Faktor - faktor yang Mempengaruhi Kepatuhan Membayar Pajak UMKM di Kabupaten Kendal. Accounting Analysis Journal. 2(1), 1-4 (2014).

[25] Susyanti, J., \& Askandar, N. S. Why Is Tax Knowledge and Tax Understanding Important?. JEMA: Jurnal Ilmiah Bidang Akuntansi Dan Manajemen. 16(2), 187 (2019).

[26] Wicaksono, R. Faktor - Faktor yang Mempengaruhi Kepatuhan Wajib Pajak Usaha Mikro Kecil dan Menengah (UMKM) dalam Membayar Pajak Sesuai PP No.46 Tahun 2013 pada UMKM di Kabupaten Bantul. Jurnal Fokus Bisnis. 15(2), 1-21 (2016).

[27] Lubua, E. W. Influencing Tax Compliance in SMES Through the Use of ICTS. International Journal of Learning, Teaching and Educational Research. 2(1), 80-90 (2014).

[28] Ahmad Farhan Alshir'ah, Hijattulah Abdul-Jabbar, R. S. S. Determinants of sales tax compliance in small and medium enterprises in Jordan : A call for empirical research. 
World Journal of Management and Behavioral Studies. 4(1), 41-46 (2016).

[29] Binh, T.-N. Tax Compliance as a Red Tape to Businesses: Conceptual Issues and Empirical Evidence from Australia. Journal of Business \& Economic Policy. 2(4), 76. (2015).

[30] Sudiartana, I. M., \& Mendra, N. P. Y. Faktor - Faktor yang Mempengaruhi Kepatuhan Wajib Pajak. Proceeding TEAM. 2, 184 (2017).

[31] Sebhat, W., \& Assfaw, A. M. Analysis of Tax Compliance and Its Determinants: Evidence from Kaffa, Bench Maji and Sheka Zones Category B Tax Payers, SNNPR, Ethiopia. Journal of Accounting Finance and Auditing Studies (JAFAS). 5(1), 32-58 (2019).

[32] World Bank, I. Access to finance for SMES. (2014). 